\title{
Hepatitis B coinfection in HIV-infected patients
}

\author{
Gabriela Jugănariu ${ }^{1,2^{*}}$, Cristina Nicolau ${ }^{2}$, Liviu Jany Prisăcariu ${ }^{2}$, Carmen Manciuc ${ }^{1,2}$, Andra Teodor ${ }^{1,2}$, Cătălina Luca ${ }^{1,2}$, \\ Carmen Dorobățt,2
}

From The 9th Edition of the Scientific Days of the National Institute for Infectious Diseases Prof Dr Matei Bals

Bucharest, Romania. 23-25 October 2013

\section{Background}

The similar routes of transmission for HIV and HBV infections place patients with either infection at greater risk for HIV/HBV co-infection. The aim of this study was to analyze the epidemiological, virological, immunological and evolutive characteristics of HIV-HBV coinfected patients in the Regional HIV/AIDS Center Iaşi.

\section{Methods}

We performed a retrospective study including 252 patients diagnosed with HIV associated with hepatitis B virus coinfection evaluated in the Infectious Diseases Hospital Iaşi between 2000-2013.

\section{Results}

HIV-HBV coinfection prevalence was $19.9 \%$. We noticed a slightly higher frequency of coinfection in males $(53.2 \%)$, most patients belonging to the age group 20-29 (86.5\%), the median age of the group being 25.56 years. The predominant route of transmission was parenteral (57.5\%), heterosexual being found in a significant proportion (40.1\%). The mean CD4 cell count was 246.20 cells/cmm, over $41 \%$ of the cases had levels between 200-499 CD4 cells/ $\mathrm{cmm}$. Individual values of plasma HIV viral load varied from undetectable levels up to a maximum of $4,600,000$ copies $/ \mathrm{mL}$, with a median value of 142,906 copies $/ \mathrm{mL}$. ALT levels in HIV and HBV coinfection varied between $10-323 \mathrm{U} / \mathrm{L}$, the average being $49.90 \mathrm{U} / \mathrm{L}$, more than $65 \%$ of subjects with pathological levels; $218 \%$ of the total cholesterol values were pathological, the mean for the group was $182.58 \mathrm{mg} / \mathrm{dL}$. Only $16.8 \%$ in the coinfected group had serum triglyceride levels below the reference $(160 \mathrm{mg} / \mathrm{dL})$. All patients in the HIV-HBV coinfected group had antiretroviral therapeutic agents with dual action anti-HIV and anti-HBV, $87.3 \%$ receiving lamivudine

\footnotetext{
* Correspondence: gabriela_juganariu@yahoo.com

1"Gr.T.Popa" University of Medicine and Pharmacy, Iaşi, Romania

Full list of author information is available at the end of the article
}

alone or in coformulation; in a small number of cases (3.6\%) we opted for tenofovir.

\section{Conclusion}

The liver injury in the context of coinfection with HBV remains a key issue in the management of patients with HIV infection and is a major cause of mortality and morbidity.

\section{Authors' details}

"Gr.T.Popa" University of Medicine and Pharmacy, laşi, Romania. 'Infectious Diseases Hospital "Sf Parascheva", Iaşi, Romania.

Published: 16 December 2013

doi:10.1186/1471-2334-13-S1-P13

Cite this article as: Jugănariu et al:: Hepatitis B coinfection in

HIV-infected patients. BMC Infectious Diseases 2013 13(Suppl 1):P13.
Submit your next manuscript to BioMed Central and take full advantage of:

- Convenient online submission

- Thorough peer review

- No space constraints or color figure charges

- Immediate publication on acceptance

- Inclusion in PubMed, CAS, Scopus and Google Scholar

- Research which is freely available for redistribution

\section{() Biomed Central}

\section{Ciomed Central}

